\title{
The Effects of Model IVS 2 MAP Progesterone, eCG, GnRH, and PGf $2 \alpha$ on Pregnancy of Tail Fat Ewes Strain Sapudi Islands Subjected to A Short-term Synchronization of Estrus
}

\author{
H.A. Hermadi ${ }^{1}$, M. Hariadi ${ }^{1}$, H. Ratnani ${ }^{2}$ \\ ${ }^{1}$ Professor, ${ }^{2}$ Lecturer, Department of Veterinary Reproduction, Faculty of Veterinary Medicine, Universitas \\ Airlangga, Surabaya, Indonesia
}

\begin{abstract}
The objective of this study was to verify the effects of engineering design of IVS 2 progesterone with 2 $\mathrm{cm}$ thick sponge and $2 \mathrm{~cm}$ length and $5 \mathrm{~cm}$ silicon plate in the middle with $13 \mathrm{~cm}$ nylon cord ties to pull the sponge position. Try to determine the effective dose of progesterone (MAP) with a dose of $60 \mathrm{mg}$ progesterone, eCG, GnRH and PGf2 $\alpha$ on pregnancy of ewes subjected to a short-term synchronization of estrus. Tail fat sheep ewes strain sapudi Islands received $60 \mathrm{mg}$ MAP sponges model IVS 2 during 12 days plus $500 \mathrm{IU}$ eCG folligon and $2.5 \mathrm{mg}$ d-cloprostenol capriglandin $(0.5 \mathrm{ml})$ submucosa vulva $24 \mathrm{~h}$ prior to IVS 2. Control groups (T0) 10 Ewes were assigned to receive $0.9 \% \mathrm{NaCl}$ solution $2 \mathrm{ml}$ im only when estrus sign showed waited for natural estrus. Group treatment 10 Ewes were (T1) IVS2 + 500 IU eCG folligon and group treatment 10 Ewes were (T2) IVS2 +500 IU eCG folligon $21.5 \mu \mathrm{g}(0.5 \mathrm{ml}) \mathrm{GnRH}$ fertagyl gonadorelin, 24 hours after withdrawal. Each group was assigned to intracervical insemination by Vaginoscopy $(\mathrm{n}=30)$. Artificial insemination was performed with a single dose of fresh semen on egg yolk skim milk dilluters. For controlled mating, females were exposed to males 48 hours after sponges removed. Ten females per treatment were subjected to transrectal ultrasound examination at 35 days late after AI. Estrous response (100.0\%), pregnancy rates (T0 80\% T1 70\% and T2 70\%), did not differ between T1 and T2 respectively ( $p$ $>0.05)$. Administration of GnRH 24 hours after IVS 2 removed does not improve pregnancy rate in estrous synchronization in Tail fat ewes strain sapudi Islands $(p>0.05)$ on day 35 .
\end{abstract}

Keywords: Artificial insemination, intravaginal MAP progesterone model IVS 2, pregnancy rate, tail fat ewes strain Sapudi Islands.

\section{Introduction}

The IVS 2 intra vaginal sponge design technique contains progesterone/MPA (medroxy progesterone acetate) with a sponge diameter of $2 \mathrm{~cm}$ and a length of $2 \mathrm{~cm}$ thick and its center contains a $\mathrm{T}$ rod made of plastic silicon. This tool was created with the aim of efficient

\section{Corresponding Author:}

\section{H.A. Hermadi}

Professor, Department of Veterinary Reproduction, Faculty of Veterinary Medicine, Universitas Airlangga, Surabaya, Indonesia e-mail: herrypro59@yahoo.com use of the hormone progesterone. Fat tailed sheep Sapudi Madura is a pure plasma of Sapudi Madura Island, East Java Indonesia. The hallmark of this sheep is having a sigmoid fat tail with an average width of $15 \mathrm{~cm}$ with a length of $25 \mathrm{~cm}$. This tail is the accumulation of fat tissue as a source of energy and is typical. The average adult weight of males reaches $35 \mathrm{~kg}$ and females $25 \mathrm{~kg}^{1}$. MPA belongs to a group of steroid hormones whose chemical composition is 6 methyl $17 \alpha$ acetoxy progesterone giving a $60 \mathrm{mg}$ MPA sponge combination with a 500 IU intra-muscular Pregnant Mare Serum Gonadotropin (PMSG) or eCG, GnRH and PGf $2 \alpha$ on pregnancy of ewes subjected to a short-term synchronization of estrus. combination will give very satisfying results. Research on the effect of giving intra vaginal sponge assemblies 
of medroxy progesterone acetate (MPA) to the speed of onset of sheep estrus, the results showed that the extraction on the 12th day was almost the same as the speed of estrus by using PGF $2 \alpha 7 \mathrm{mg}$ intra-muscular which is about 48 hours after the extraction had been tested try MPA sponge $e^{2,3,4,5}$.

The use of MPA progesterone dose and its combination with eCG folligon is given an injection of $300 \mathrm{IU}$ intra muscular on the $12^{\text {th }}$ day when the extraction of progesterone. Intra vaginal vaginal progesterone hormone given to 60 boar goats with a difference of progesterone $30 \mathrm{mg}$ and $60 \mathrm{mg}$ given intravenously for 12 days did not show estrus differences both $100 \%$ showed symptoms of lust but differed significantly in oestrous period duration $(p<0.01)$ was shorter in the control group (29.3 hours versus 28.0 hours for Indigenous and Boer goats, respectively), compared to the period induced to $60 \mathrm{mg}$. ( 31 and $32 \mathrm{~h}$ ) or $30 \mathrm{mg}$ ( $40 \mathrm{~h}$ compared to 34 h) for each Boer goat ${ }^{6}, 60 \mathrm{mg}$ in case in ewe ${ }^{7}$. The use of eCG (PMSG folligon) injection applied with the use of intravaginal sponges MPA. 300 IU intra-muscularly coinciding with the removal of sponge day 12 and the dose of $500 \mathrm{IU}$ eCG in ewe on the same day followed by estrus on the day to day 14 . The combined use of progesterone and PGf2 $\alpha$ on ewes subjected to a shortterm synchronization is usually used when injecting $2.5 \mathrm{mg}$ d-cloprostenol capriglandin $(0.5 \mathrm{ml})$ submucosa vulva for efficient use or general dosage intra-muscularly $7.5 \mathrm{mg}$ or $(1.5 \mathrm{ml})$ is done simultaneously when sponge release progesterone aims to lyse the corpus luteum ${ }^{8}$. The combination of the GnRH hormone in this study aims to grow follicles when injected on day 0 can serve to stimulate anterior hypophysis to release FSH to stimulate follicular growth in the follicular phase and if injected the $13^{\text {th }}$ day after being removed vaginal sponge progesterone on the 12th day will serve as a trigger anterior hypophysis to release LH which functions to ovulate the gravian follicle. Fertagyl which contains the GnRH hormone Gonadorelin is usually given at a dose of 25 ug intra-muscularly 9 .

\section{Materials and Method}

A total of 30 Tail fat ewes strain sapudi Islands that were confirmed to be 2 years old that had a body score of at least 2 were previously treated with milk concentrate A protein 15-17\% (Phok Phand) $0.05 \mathrm{~kg} /$ day/head for increased of body score condition(16, 19), for 1 month randomly divided into 2 groups with each treatment received 10 replications of T0 (control
Groups) 10 ewe: Injected $0.9 \% \mathrm{NaCl}$ solution $2 \mathrm{ml}$ intra muscular injections of control group, and $\mathrm{T} 1$ (treatment groups 1) 10 ewe: IVS2 MAP progesterone, eCG and PGf2 combinated and T2 (treatment groups 2) 10 ewe: IVS2 MAP progesterone, eCG, PGf2 and GnRH. Insemination using fresh semen is performed when signs of estrus Artificial insemination was performed with a single dose of fresh semen on egg yolk skim milk dilluters. For controlled mating, females were exposed to males 48 hours after sponges removed. IVS 2 design type specifications required material sponge imprints diameter $2 \mathrm{~cm}$ long Thick $2 \mathrm{~cm}$ in the middle there is a silicone $\mathrm{T}$ shape with a length of $5 \mathrm{~cm}$ and is equipped with a $15 \mathrm{~cm}$ long rope. Sponge contains Medroxy Progesterone Acetate (MPA) 60 mg Cyprofloxacine 500 grams in vaseline alba.

Treatment and control groups are: $\mathrm{T} 0$ (control Groups) 10 ewe: Injected $0.9 \% \mathrm{NaCl}$ solution $2 \mathrm{ml}$ intra muscular, T1 (treatment groups 1) 10 ewe: IVS2 MAP progesterone, eCG and PGf2 combinated, T2 (treatment groups 2) 10 ewe: IVS2 MAP progesterone, eCG, PGf2 and GnRH.

Statistical design and analysis: The research design used was a complete random design and data analysis was carried out using proportional quantitative and qualitative analysis on estrus and pregnancy in Tail fat ewes strain sapudi Islands. Some types of data analysis that will be used are: Analysis of Variance Analysis (ANOVA) and Honest Difference Test (SPSS 22) ${ }^{10}$.

\section{Results and Discussion}

The results showed no significant differences $p$ $>0.05$ in estrus sign, where average estrus of the 14th all of p0 and groups of treatment showed real estrus. This event allows the ovaries to give the opportunity to develop sub-ordinate follicles into de Graaf follicles in the injected Pgf $2 \alpha$ lysis stimulus of corpus luteum periodicum on day 12 and after that on the $14^{\text {th }}$ day all of them group showed symptoms of $100 \%$ estrus sign. Contain FSH and LH on eCG folligon can be suport follicle grow on folliculary phase on 12 days until $14^{\text {th11 }}$. The LH receptor is also expressed on granulosa cells. have reported that the signaling pathways of LH do not completely overlap, and this fact may have implications for LH use in assisted reproductive techniques (ART) a gonadotropin-releasing hormone $(\mathrm{GnRH})$ agonist, initially presented as a substitute for hCG, has led to a new 
era of administering a GnRH agonist followed by hCG triggering for ovulation to give 24 hours after removed of the sponge ${ }^{12}$. The response to superovulation, yield and quality of the embryo, is evaluated after increasing the time of exposure to exogenous progesterone during superstimulation, with or without the addition of GnRH agonists. Thirty-four females of the Santa Inês type were synchronized with an intravaginal progesterone device with the addition of $\mathrm{GnRh} 25 \mathrm{mg}$ of gonadorelin when removed device in day 12 . These results indicate the relationship of progesterone exposure longer plus the administration of GnRH in during the release of progresterone device is an alternative to increase the rate of oocyte fertilization when insemination time is still used AI twice at 36 hours dan 42 hours after the release of the progesterone device ${ }^{13,14}$.

Table 1. The effects of model IVS 2 MAP progesterone, eCG, GnRH, and PGf $2 \alpha$ on pregnancy of Tail fat ewes strain sapudi Islands subjected to a short-term synchronization of estrus.

\begin{tabular}{|l|c|c|c|}
\hline Group of Treatment & T0 & T1 & T2 \\
\hline $\begin{array}{l}\text { Number of Tail Fat } \\
\text { Strain Island }\end{array}$ & 10 & 10 & 10 \\
\hline Duration of estrus (h) & $30 \pm 8$ & $30 \pm 61$ & $30 \pm 12$ \\
\hline $\begin{array}{l}\text { Occurrence of estrus } \\
(\%)\end{array}$ & $100(10 / 10)$ & $100(10 / 10)$ & $100(10 / 10)$ \\
\hline $\begin{array}{l}\text { Pregnat observation } \\
\text { used USG }\end{array}$ & 80.00 & 70.00 & 70.00 \\
\hline
\end{tabular}

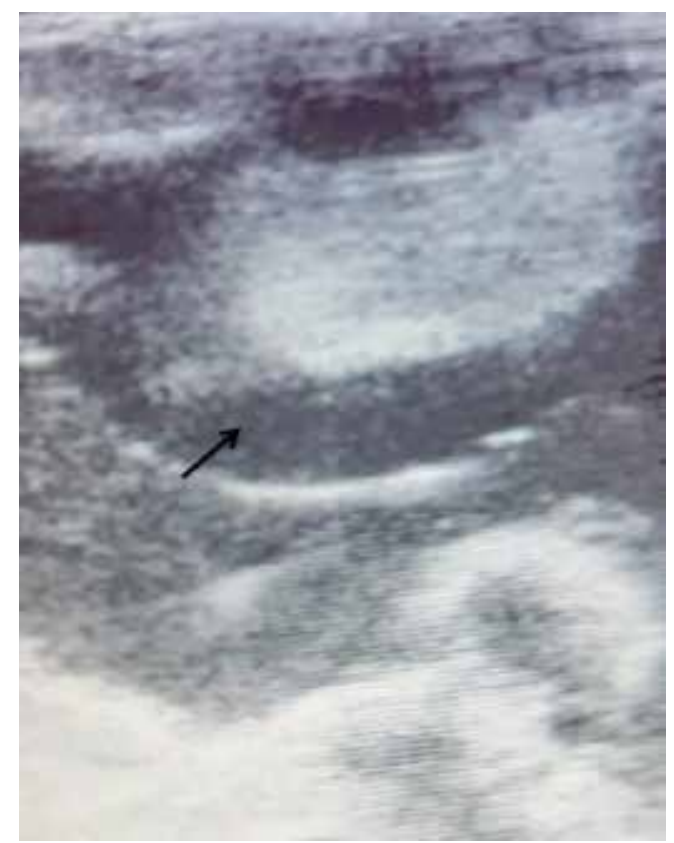

Figure 1. The result of pregnancy 35-day detection via ultrasonography showed.
The results showed no significant differences where the injection of PGF2 $\alpha$ and eCG of the 12 nd all of The Tail fat ewes strain sapudi Islands showed real estrus. This event allows the ovaries to give the opportunity to develop PGF $2 \alpha$ stimulus on day 12 after removed sponge and eCG grow follicles in the follicular phase. After AI on the 14th day all of them in group T0, T1 and $\mathrm{T} 2$ showed positive pregnancies of $80 \%$ (8 tail) in control groups, T1 70\% (7 tails) and T2 70\% (7 taisl) in treatments groups. The uterus, and the fetus, have been described (Amrozi and Setiawan, 2011). Pregnancy diagnosis using USG on day 24 after AI or day 48 shows embryo images with hyper ecogenic type Transrectal ultrasonography real-time B-mode shows embryonic vesicles early on the 12 th day after marriage, but sensitivity is very low (12\%) and higher on the 25th day after the marriage. Transcutaneous ultrasonography achieves the greatest accuracy for pregnancy diagnosis (94-100\%) and determination of the number of fetuses $(92-99 \%)^{15}$.

Administration of GnRH 24 hours injected after IVS 2 removed does not improve pregnancy rate in estrous synchronization in Tail fat ewes strain Sapudi Islands $(p<0.05)$. Perhaps as a reason why GnRH does not show potentiation of increased number of pregnancies, it appears in the $\mathrm{T} 1$ group that the ability of endogenous LH or the ability of eCG can grow folicels based on the ability of the FSH they contain to be able to develop intra-cellular LH growth in the pituitary ${ }^{16}$. In another study, all sheep were planted with progesterone with a combination of $400 \mathrm{IU}$ eCG and $25 \mathrm{ug}$ GnRH 36 hours after removed progesterone, apparently GnRH injection did not affect the efficiency of estrus synchronization progestin with $\mathrm{GnRH}, 85.1 \%$ compared to progestin without GnRH, 90.3\% and pregnancy rates after laparoscopic artificial insemination progestins with GnRH, 53.7\% compared to progestins without GnRH, $61.3 \%$. Here we dare ourselves that GnRH is less efficient if it turns out that $\mathrm{T} 1$ compared to $\mathrm{T} 2$ seems to be no significant difference. Another reason that hormones stimulate the release of gonadotropins $(\mathrm{GnRH})$ is a key neuro-peptide that controls the reproductive function of vertebrates, especially in ewe expected to experience spontaneous ovulation, ovarian steroids released by mature ovarian follicles controlling pulsatile patterns of $\mathrm{GnRH}$ release from the hypothalamus, in turn, stimulates the preovulatory secretions of the luteinizing hormone (LH) by the anterior pituitary gland ${ }^{17}$. 
Intravaginal progestagen sponge in sheep treated with two doses of 100 microgram cloprostenol while releasing progestagen sponge for 14 days. The percentage of sheep that responded to the synchronization treatment with signs of estrous behavior was similar at $72.4 \%$. The use of progestagens resulted in the highest follicular diameter being higher to $5.9 \mathrm{~mm}$, and showed the same fertilization rate of $70.6 \%{ }^{18}$. The new technology 50 $\mu \mathrm{g}$ of GnRH (Acegon, Lab. Syva, Leon, Spain), was prepared by mixing $1 \mathrm{~mL}$ of Acegon (equivalent to 50 $\mu \mathrm{g}$ of $\mathrm{GnRH}$ ) with $4 \mathrm{~mL}$ of propylene-glycol, protocols based on a short-term intravaginal progesteron treatment and a single subcutaneous dose of $\mathrm{GnRH}$ in propyleneglycol at $36 \mathrm{~h}$ after progestagen removal induced. $80 \%$ of the animals developed estrus in a narrow timing $75 \%$. administration of $\mathrm{GnRH}$ in propyleneglycol recommended in the intravaginal progesterone technique $^{19}$. The conception rate of the G14 days of P4 bunch was measurably higher than that of the other bunches $(83.3 \%) .14$ days of progeteron norgestomet treatment delivered higher conception rates and a more prominent number of pregnancies at the starting of the breeding season. Protocol for estrus synchronization the norgestomet implants were cut in half using scissors. One half (containing $1.5 \mathrm{mg}$ norgestomet) was implanted subcutaneously in the ear of each ewe. At the time of implant removal, 400 IU of eCG (Folligon; Intervet) and $22.5 \mu \mathrm{g}$ D-cloprostenol (Preloban; Intervet) were injected intramuscularly into every ewe and AI $0.5 \mathrm{ml}$ semen $^{20}$.

\section{Conclusion}

In summary, the effects of model IVS 2 MAP progesterone, eCG, GnRH, and PGf2 on pregnancy of subjected to a short-term synchronization of estrus followed by estrus and pregnancy of the tail fat ewes strain sapudi Islands sign of estrus will be shown on day 14 and served of AI. 35 days late after AI treatment between control a research groups used diagnosis of pregnancies using USG for pregnancies diagnose. The result showed that no different $p>0.05$ between control and treatment groups in estrus and pregnantion. Injected of GnRH 24 hours after removed of sponge does not improve estrus or pregnancy rate in ewes.

Conflict of Interest: The author declare that they have no conflict of interest.

Source of Funding: This study supported by the Ministry of Education and Culture of the Republic of Indonesia
Acknowledgements: We thank Arif Nur Muhammad Ansori for editing the manuscript.

Ethical Approval: This study was approved by the Faculty of Veterinary Medicine, Universitas Airlangga, Surabaya, Indonesia.

\section{References}

1. Sudarmono, A.S., Sugeng, Y.B. Beternak Domba. Jakarta: Penebar Swadaya; 2011.

2. Almadaly E, Ashour M, El-Kon I, Heleil B, Fattouh E. Efficacy of various synchronization protocols on the estrus behavior, lambing rate and prolificacy in rahmani Egyptian ewes during the non-breeding season. Asian J Anim Vet Adv. 2016; 11: 34-43.

3. Cavalcanti AS, Brandão FZ, Nogueira LAG, Fonseca JF. Effects of GnRH administration on ovulation and fertility in ewes subjected to estrous synchronization. R. Bras. Zootec. 2012; 41(6): 1412-1418.

4. KumarESA, Reddy KR, Reddy AG, Raghavavender KBP, Kumar DA, Ramsingh L. Efficacy of estrus synchronization protocols on reproductive performance in goats. Pharma Innov J. 2018; 7(3): 3-6.

5. Zeleke M, Greyling JPC, Schwalbach LMJ, Muller T, Erasmus JA. Effect of progestagen and PMSG on oestrous synchronization and fertility in Dorper ewes during the transition period. Small Rum Res. 2005; 56: 47-53.

6. Greyling JPC, van Der Nest M. Synchronization of oestrus in goats: Dose effect of progestagen. Small Rum Res. 2000; 36: 201-207.

7. Langford GA. Influence of PMSG and time of artificial insemination on fertility of progestogentreated sheep in confinement. J Anim Sci. 1982; 54(6): 1205-1211.

8. Gibbons AE, Fernandez J, Bruno-Galarraga MM, Spinelli MV, Cueto MI. Technical recommendations for artificial insemination in sheep. Anim Reprod. 2019; 16(4): 803-809.

9. Fonseca JF, Torres CA, Santos AD, Maffili VV, Amorim LS, Moraes EA. Progesterone and behavioral features when estrous is induced in Alpine goats. Anim Reprod Sci. 2008; 103(3-4): 366-373.

10. Gonzalez-Bulnes A, Veiga-Lopez A, Garcia P, Garcia-Garcia RM, Ariznavarreta C, Sanchez MA, 
Tresguerres JA, Cocero MJ, Flores JM. Effects of progestagens and prostaglandin analogues on ovarian function and embryo viability in sheep. Theriogenology. 2005; 63(9): 2523-2534.

11. Faigl V, Vass N, Jávor A, Kulcsár M, Solti L, Amiridis G, Cseh S. Artificial insemination of small ruminants - a review. Acta Vet Hung. 2012; 60(1): 115-129.

12. Morris MJ, Kaneko K, Walker SL, Jones DN, Routly JE, Smith RF, Dobson H. Influence of lameness on follicular growth, ovulation, reproductive hormone concentrations and estrus behavior in dairy cows. Theriogenology. 2011; 76(4): 658-668.

13. Cole LA. Biological functions of hCG and hCGrelated molecules. Reprod Biol Endocrinol. 2010; 8: 102 .

14. Blaschi W, Lunardelli PA, Marinho LS, Max MC, Santos GM, Silva-Santos KC, Melo-Sterza FA, Baldassarre H, Rigo TR, Seneda MM. Effects of progestagen exposure duration on estrus synchronization and conception rates of crossbreed ewes undergoing fixed time artificial insemination. J Vet Sci. 2014; 15(3): 433-437.
15. Ochoa-Bernal MA, Fazleabas AT. Physiologic events of embryo implantation and decidualization in human and non-human primates. Int J Mol Sci. 2020; 21(6): 1973.

16. Scott PR. Applications of diagnostic ultrasonography in small ruminant reproductive management. Anim Reprod Sci. 2012; 130: 184186.

17. Año-Perello A, Santos-Jimenez $Z$, Encinas $T$, Martinez-Ros P, Gonzalez-Bulnes A. Use of gnrh for synchronization of the follicular wave in assisted reproductive technologies in sheep: A preliminary study. Animals. 2020; 10(7): 1208.

18. Bakker J, Baum MJ. Neuroendocrine regulation of GnRH release in induced ovulators. Front Neuroendocrinol. 2000; 21(3): 220-262.

19. Kaponis A, Chronopoulou E, Decavalas G. The curious case of premature luteinization. J Assist Reprod Genet. 2018; 35(10): 1723-1740.

20. Santos-Jimenez Z, Guillen-Gargallo S, Encinas T, Berlinguer F, Veliz-Deras FG, Martinez-Ros $P$, Gonzalez-Bulnes A. Use of propylene-glycol as a cosolvent for GnRh in synchronization of estrus and ovulation in sheep. Animals. 2020; 10(5): 897. 